\author{
지압과 온열의 조합마사지가 인체의 \\ 스트레스 완화에 미치는 영향 평가 \\ 이대원 ${ }^{1,2}$ - 박지형 ${ }^{1,2}$ - 엄시내 ${ }^{1,2}$ - 김도원 ${ }^{1}$ - 조승현 ${ }^{3}$ - 고창용 ${ }^{4}$ - 김한성 1,2 \\ ${ }^{1}$ 연세대학교 의공학부 \\ 2연세대학교 프라운호퍼 의료기기 공동연구센터 \\ 3(주) 누가의료기 \\ ${ }^{4}$ 재활공학연구소 R\&D 1팀
}

\title{
Effects of Combined Stimulus on Stress Relief
}

\section{Dae Won Lee ${ }^{1,2}$, Ji Hyung Park ${ }^{1,2}$, Si Nae Eom ${ }^{1,2}$, Do Won Kim ${ }^{1,2}$, Syung Hyun $\mathrm{Cho}^{3}$, Chang-Yong $\mathrm{Ko}^{4}$ and Han Sung Kim ${ }^{1,2}$}

\author{
${ }^{1}$ Department of Biomedical Engineering, Yonsei University, Wonju City, Kangwon-do 220-710, Korea \\ ${ }^{2}$ Yonsei Fraunhofer IZFP Medical Device Lab, Yonsei University, Wonju City, Kangwon-do 220-710, Korea \\ ${ }^{3}$ Nuga Medical Co., Ltd, Kangwon-do 220-820, Korea \\ ${ }^{4}$ Research \& Development 1 Team, Korea Orthopedics \& Rehabilitation Engineering Center, Incheon 403-712, Korea
}

(Received September 4, 2012. Accepted December 11, 2012)

\begin{abstract}
This study was designed to investigate the effect of a combined stimulus which was composed of chiropractic massage and thermotherapy on the relief of mental and physical stress. Fifteen healthy male subjects were treated with three type of stimuli; control (without any stimulus), a single stimulus (only chiropractic) and a combined stimulus. To evaluate the effects of stimuli, visual analogue scale (VAS), trunk extension, electromyogram (EMG) on erector spinae muscle and electrocardiogram (ECG) were measured and analyzed before and after stimuli. In the control group, there were no significant changes in EMG root mean square (RMS) value and low Frequency / high Frequency $(\mathrm{LF} / \mathrm{HF})$ ratio $(\mathrm{p}>0.05, \mathrm{p}>0.05)$. However, both stimulus groups showed significant increases in trunk extension and EMG RMS values ( $<<0.05, \mathrm{p}<0.05)$, but significant decreases in LF/HF ratios $(\mathrm{p}<0.05)$. Particularly the decrement rate in $\mathrm{LF} / \mathrm{HF}$ ratio was significantly higher in the combined stimulus group than that in the single stimulus group $(\mathrm{p}<0.05)$. Also, a significantly lower VAS was recorded after combined stimulus. Our findings indicate that the combined stimulus might not only improve flexibility and strength of muscle, but also active parasympathetic nerve activity. The combined stimulus may thus contribute to relieve the stress and to enhance the muscle function.
\end{abstract}

Key words: Chiropractic, Thermotherapy, Combined stimulus, Stress, Visual Analogue Scale, Electromyogram, Electrocardiogram, Heart Rate Variability

Corresponding Author : Han Sung Kim

Department of Biomedical Engineering, Yonsei University, Wonju City, Kangwon-Do 220-710, Korea

TEL: 82-33-760-2342 / FAX: 82-33-760-2913

E-mail: hanskim@yonsei.ac.kr

이 논문은 2012 년도 정부(교육과학기술부)의 재원으로 한국연구재 단의 지원을 받아 수행된 해외우수연구기관유치사업 연구임(201000757).

\section{I. 서 론}

최근 과학기술과 사회구조의 급격한 변화로 인하여 많은 현대인들은 정신적 스트레스에 노출되어있다. 또한 장시간 앉은 자세의 업무환경은 정신적 스트레스뿐만 아니라 육체 적 스트레스를 가중시켜 신체 중 허리에 특히 많은 피로를 유발시키며, 심할 경우 만성적인 질병을 일으키게 되어 외 
과적인 처치까지도 필요하다[1,2]. 이러한 외과적 처치는 많 은 시간 및 비용이 요구되며 특히 고령자의 경우 수술의 어 려움뿐만 아니라 합병증 및 후유증이 동반되기도 한다[21]. 이에 따라 최근에는 스트레스의 효율적인 관리와 근골격계 통증 예방 및 치료, 재활을 위해 일상에서 쉽게 접할 수 있 는 비외과적 처치 방법들이 대두되고 있다[2].

그 중 마사지는 가장 널리 쓰이는 중 비외과적 처지 방법 중 하나이며 외부에서 특정 자극을 줌으로 체내의 자율신경 계에 영향을 미쳐 교감신경과 부교감신경을 활성화시키는데 이들의 길항 작용을 통해 인체의 조직과 기관의 생리적 균 형을 유지하게 되고 이에 따라 혈액순환이 개선되고 스트레 스의 해소에 영향을 준다[3,4]. 마사지 중 하나인 온열 자극 은 일상에서 쉽게 접할 수 있으며 그 효능으로는 심부의 온 도를 상승, 혈관의 확장을 통한 혈액 순환 촉진, 신진대사 활 성화, 그리고 조직의 기능 재생 개선 등이 있다[5]. 정인철 등[6]은 온열 자극 전후의 심 평균 심박동수(mean Heart Rate, HR)의 감소와 부교감신경의 활성화를 통해 온열 마 사지에 의한 스트레스의 감소를 확인하였다. 다른 마사지 중 하나로 지압마사지가 있으며 근골격계의 기능 회복, 스트레 스 완화 등의 효과가 있다. Diego 등[7]은 고강도 지압마사 지가 저강도 지압마사지에 비하여 안정된 뇌파와 심박수를 보임을 확인하였다. 김용대 등[8]은 전동마사지 사용 전후로 20 명의 피검자의 주관적 불편도 평가인 VAS (visual analog scale)설문 조사와 심박변이도(heart rate variability, $\mathrm{HRV})$ 분석을 수행하여 마사지 이후에 VAS의 감소와 부교 감신경 지표의 증가를 보여 마사지가 스트레스를 완화시켜 줌을 확인하였다. 특히 고강도 마사지가 저강도 마사지에 비 하여 그 감소폭이 더 크며 이로 인하여 스트레스 완화효과 가 더 큰 것을 확인하였다. Ogura 등 [27]은 VAS 평가를 통 해 지압마사지에 따른 실험참여자의 심리적 스트레스 완화 효과를 알아보았으며, 마사지 후 VAS의 유의한 감소를 보 여 지압마사지가 심리적 스트레스완화에 효과적임을 확인하 였다. 육체적 스트레스는 근육의 긴장과 밀접한 관계가 있 으며 마사지를 통한 근육의 이완과 근력 회복으로 육체적 스트레스의 완화가 평가되었다[26]. 이승열 등[9]은 하체의 최대부하운동 후 지압마사지의 수행이 근력 회복에 미치는 영향을 알아보기 위해 등속성 장비를 이용하여 무릎관절의 신전과 굴곡을 위한 굴근력과 신전력 측정 및 분석을 수행 하였으며, 마사지 후 햄스트링 근육(hamstring muscle)과 대퇴사두근(quadriceps)의 최대근력 증가를 통해 근력 회 복에 긍정적인 경향을 알아보았다. Suter 등[22]은 하체 지 압마사지의 수행이 근력 회복에 미치는 영향을 알아보기 위 해 무릎의 최대 토크(torque)와 슬관절 신전근(knee extensor muscles)의 근전도(electromyogram, EMG) 측정 및 분석을 수행하였으며, 마사지 후 최대근력 증가를 통해
근력 회복에 긍정적인 경향을 알아보았다. Shambaugh[23] 은 척추지압마사지가 척추근육이완에 미치는 영향을 알아보 기 위해 승모근(trapezius)과 척추기립근(erector spinae) 에서 $\mathrm{EMG}$ 를 측정하여 동일한 동작에서 발생하는 근육의 활성의 변화를 통해 척추 근육의 이완과 스트레스의 완화를 평가하였다. 권형수 등[18]은 허리 및 하체 지압마사지가 인 체의 유연성에 미치는 영향을 알아보기 위해 마사지 전후의 체전굴, 체후굴의 유연성 평가를 수행한 결과 마사지 후의 체전굴과 체후굴 측정값이 증가하는 경향을 보여 지압마사 지가 유연성 향상에 긍정적인 영향을 확인하였다.

이와 같이 마사지에 대한 관심의 증대로 그 효과의 연구 가 여러 분야에서 시행되어 인체에 긍정적인 영향이 보고되 고 있다. 최근 둘 이상 조합한 자극이 인체에 더 유익할 것 이라는 주장이 제시 되고 있지만[24], 이에 대한 실제 연구 는 거의 없는 실정이다. 또한 기존연구들에서는 주로 한가 지의 생체신호만 사용하여 스트레스의 완화 정도를 정량적 으로 평가였지만, 하나의 파라미터로 육체적, 심리적 스트레 스의 완화 정도를 평가하는 것은 부족하다. 본 연구에서는 피검자의 척추에 일정시간 동안 지압과 온열의 조합마사지 를 가하였고 이에 따른 스트레스에 미치는 영향을 알아보기 위해 VAS, EMG와 ECG 측정을 수행하였다.

\section{II. 실험 방법}

\section{1. 실험 대상 및 설계}

본 실험은 연구대상자들은 연세대학교 원주(매지)캠퍼스 인체시험심의위원회의 심의규정에 따라 수행 되었다 (인체 시험심의위원회 승인번호: 2011-15).

신체 건강한 20 대 성인 남성 ((평균(표준편차)) 나이: 26 세( \pm 3$)$, 몸 무게: $74 \mathrm{~kg}( \pm 4.5)$, 키: $170 \mathrm{~cm}( \pm 6.3)) 15$ 명이 모집되었다. 조합 자극 휴식이 인체의 근 기능과 자율신경 계에 미치는 영향을 알아보기 위해 대조군, 지압마사지군, 그리고 조합마사지군으로 나누고 각각의 휴식 시 자극 조건 에 차이를 두어 휴식 전과 후의 $\mathrm{EMG}$ 및 $\mathrm{ECG}$ 측정 분석 을 통한 비교실험이 수행되었다.

실험 참여자들의 실험 적응에 따라 실험 결과에 미치는 영향을 배제하기 위해 실험 참여자들은 $2 \sim 3$ 일 간격으로 총 3 회 실험에 참가하여 무작위로 각 군의 휴식 방식이 적용되 었다. 또한 실험에 앞서 일반적인 생체 리듬을 위해 실험참 여자들은 전날 충분한 휴식을 취하고 실험에 참여하였으며, 모든 실험은 오후 2 시에서 5 시 사이에 진행되었다.

실험 순서는 다음과 같이 설정되었다. 실험 참여자는 실 험에 앞서 VAS를 작성한 후 체후굴 자세(trunk extension) 를 취하여 인체의 유연성 평가하기 위해 바닥에서 턱까지의 높이를 측정함과 동시에 L3에서의 EMG 신호를 측정하였 
다[13,19]. 체후굴 평가 측정이 끝난 후 실험 참여자는 각 군의 자극 조건에 따라 침대 또는 조합자극기에 누어 $\mathrm{ECG}$ 측정 준비 및 10 분 정도의 휴식시간을 취한 후 5 분 동안 $\mathrm{ECG}$ 측정되었다. 본 실험에 사용된 조합 자극기(NM-5000, Nuga Best, Korea)는 침대형으로 사용자가 누어서 조합자 극을 받을 수 있다. 조합자극기의 내부에는 롤러와 원적외 선 투광기가 결합되어있어 지압의 단일자극과 온열과 지압 의 조합자극을 가할 수 있지만, 온열 자극만을 따로 가할 수 없다. 또한 마사지시 온도를 $30 \sim 70^{\circ} \mathrm{C}$ 로 설정할 수 있으며, 인체의 척추를 완벽하게 모사하여 척추의 곡선을 따라 자극 이 가능하도록 설계되어 있다. 따라서 본 실험에서는 일정 시간 동안 일정한 온도와 압력의 조합마사지를 각 참여자에 게 수행하기 적합하여 본 조합 자극기가 사용되었다.

각 군의 자극 조건은 다음과 같다. 대조군(control group, $\mathrm{CON})$ 은 아무런 자극 없이 간이 침대에 누어 휴식을 취하게 하였고, 단일마사지군(single massage group, SMG)은 본 조합 자극기에 누어 지압마사지만 받게 하였다. 조합마사지 군(multiple massage group, $\mathrm{MMG}$ )은 누운 상태에서 척 추 지압마사지를 받게 하였으며 동시에 약 $60^{\circ} \mathrm{C}$ 의 온열마 사지를 받게 하였다. 모든 군의 휴식은 20 분동안 수행되었 으며, 휴식 중 수면은 제한 되었다. 모든 실험 조건 수행이 완료된 후, 각 군의 자극 조건에 따른 참여자의 신체적 변화 를 알아보기 위해 초기 측정자세와 동일한 자세로 5 분간 $\mathrm{ECG}$ 를 측정한 후 체후굴 평가, $\mathrm{EMG}$ 신호 측정 및 $\mathrm{VAS}$ 작성을 수행하였다. 그림 1 은 본 실험의 절차를 보여준다.

\section{2. 주관적 불편도 측정}

실험참여자의 심리적 스트레스 정도를 평가하기 위해 $\mathrm{VAS}$ 를 시행하였다. VAS는 특정 질환 이 없는 일반인을 대 상으로 하는 심리적 스트레스 평가로 사용되었으며 대상자 의 주관적으로 느끼는 스트레스 정도를 측정한다[8,27]. 10 $\mathrm{cm}$ 의 선에 한쪽에는 통증이 없음을 기록하고 반대 편에는 가장 높은 정도의 고통을 기록한 후 평가 대상자가 그 때 느끼는 통증을 선위에 표시하여 그룹 별로 평균을 내고 처
치에 따른 전과 후의 변화를 비교하였다.

\section{3. 체후굴 동작을 통한 $\mathrm{EMG}$ 측정 및 분석}

각 군의 자극 조건이 인체 척추 부위의 근 기능에 미치는 영향을 알아보기 위해 체후굴 동작이 수행되었다. 체후굴 평 가는 척추의 후방 유연성을 보기 위한 테스트나 허리의 근 피로도를 평가할 때 사용되며 $[10,19]$, 실험 참여자가가 엎 드린 자세로 하체의 힘이나 반동을 이용하지 못하도록 대퇴 부가 고정된 상태에서 상체를 드는 동작을 수행할 때 지면 에서부터 참여자의 턱까지의 높이 측정을 평가의 기준으로 한다[10]. 높이 측정은 $0.1 \mathrm{~cm}$ 의 단위로 측정되었으며 3 회 의 측정 결과 좋은 기록이 선택되었다. 또한 체후굴 동작 수 행 시 $\mathrm{EMG}$ 신호 측정이 동시에 수행되었다. 체후굴 동작의 주동근으로 사용되는 척추세움근(erector spinae muscle)에 서의 $\mathrm{EMG}$ 신호 측정을 위해 참여자의 척추중심선을 기준 으로 L3 위치에서 좌우 $4 \mathrm{~cm}$ 떨어진 위치에 표면 전극이 부착되었다[10-12,19]. 측정 장비로는 MP150 data acquisition system과 EMG100C amplifier (Biopac Systems Inc. USA)이 사용되었다.

측정된 $\mathrm{EMG}$ 신호는 체후굴 동작 시 척추세움근에서 발 생하는 최대 근력을 알아보기 위해 RMS (root mean square)값을 취하여 최대 근력 값이 도출되었다. $\mathrm{EMG}$ 의 $\mathrm{RMS}$ 값은 전기적 신호를 수치화 함으로써 원 신호의 수학 적인 정보를 나타내며, 다른 분석에 비해 근육이 수축하는 동안 운동단위(motor unit)의 생리적인 활동을 완벽하게 반 영한다[10,13].

\section{4. $\mathrm{ECG}$ 측정과 $\mathrm{HRV}$ 분석}

$\mathrm{ECG}$ 신호는 $1000 \mathrm{~Hz}$ 의 샘플링과 1000 의 gain값으로 ECG100C (Biopac Systems, Inc, USA)를 이용하여 얻어 졌으며, $35 \mathrm{~Hz}$ 의 low-pass 필터와 $0.5 \mathrm{~Hz}$ 의 하이 패스 필 터가 적용되었다. $\mathrm{ECG}$ 신호 측정을 위해 표준사지유도법 (standard limb lead)이 사용되었으며 이에 따라 참여자의 양 손목과 왼 발목에 표면 전극이 부착되었다.

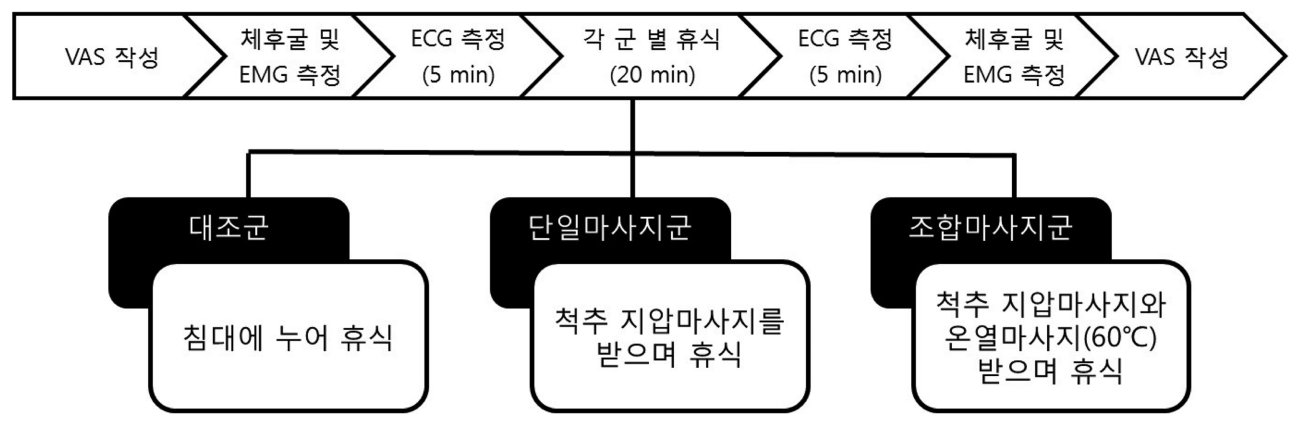

그림 1. 실험의 절차

Fig. 1. Flow chart of the experiment 
$\mathrm{ECG}$ 신호의 분석으로는 $\mathrm{HRV}$ 가 사용되었다. $\mathrm{HRV}$ 는 $\mathrm{ECG}$ 를 이용하여 자율신경계의 기능을 측정할 수 있는 방 법으로 본 실험에서는 $\mathrm{HRV}$ 의 시간영역 분석을 이용하여 참 여자의 평균심박수 변화 관찰과 PSD (power spectrum density)를 이용한 주파수 영역 분석을 이용하여 교감신경 과 부교감신경의 활성을 수치적으로 도출되었다. $\mathrm{PSD}$ 는 측 정된 $\mathrm{ECG}$ 의 $\mathrm{QRS}$ complex 중 최고점인 $\mathrm{R}$ 포인트에서 다 음 $\mathrm{R}$ 포인트까지 구간의 시간을 이용하여 주파수 영역으로 계산된다. 고속 퓨리에 변환(Fast Fourier Transform (FFT, 1024point))을 사용하여 Matlab 2011 (MathWorks, USA)을 통해 시간-주파수 변환을 수행되었다. 일반적으로 $\mathrm{HRV}$ 의 $\mathrm{PSD}$ 는 스펙트럼 곡선의 일정 주파수 범위를 적 분한 값으로 나타나며, 주파수 영역 중 $0.04 \sim 0.15 \mathrm{~Hz}$ 대역 (low frequency, LF)은 교감신경 활성의 지표로, 0.15 0.4 $\mathrm{Hz}$ 주파수 영역(high frequency, $\mathrm{HF}$ )은 부교감신경 활성 의 지표로 알려져 있다[14,15,25]. 동일 참여자 내에서 다 른 생리적 환경에서 주파수 성분들을 비교할 때 개인 차에 의한 절대값 간에는 편차가 매우 크기 때문에 이를 총 전력 에서 $0.04 \mathrm{~Hz}$ 이하 범위의 값을 땐 나머지 값으로 각 주파수 성분을 나누는 표준화(normalization)를 거쳐 상대값(normalized unit, nu)로 환산되었다[15,16,17]. 표준화가 된 값은 $\mathrm{LF} / \mathrm{HF}$ 비를 통해 자율신경계의 반응을 수치적으로 표 현되었다.

\section{5. 통계 분석}

각 군의 자극 조건에 따른 $\mathrm{EMG-RMS}$ 와 ECG-HRV의 휴식 전과 후의 차이를 검정하기 위해 대응표본 $\mathrm{T}$ 검정 (paired T-test)을 수행하였다. 또한 참여자들의 신체적 특 성 및 실험 전 생리적 상태를 고려하여 각 군간의 유의한 차 이를 확인 하기 위해 공분산분석(Analysis of Covariance, $\mathrm{ANCOVA})$ 이 적용되었으며, 이를 위해 실험 참여자의 실험 전과 후의 생체신호 데이터를 각각 공변량과 종속변수로 두 고 각 군의 자극 조건이 모수 요인으로 설정되었다. 각 군

\section{Visual Analog Scale}

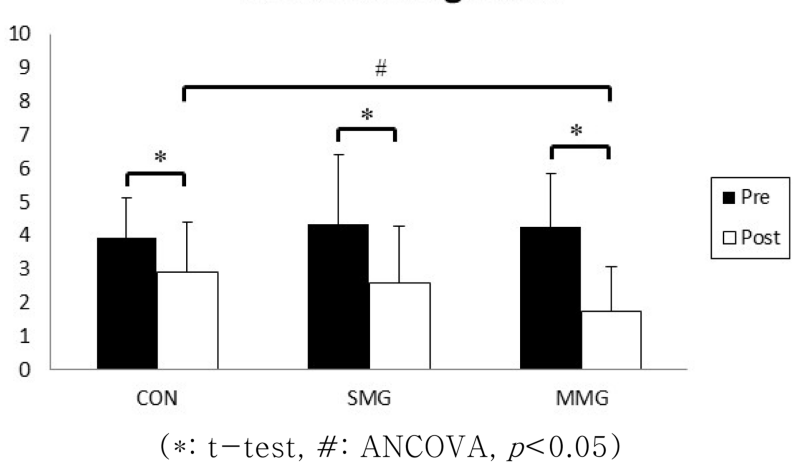

그림 2. VAS의 변화

Fig. 2. Changes in visual analogue scale (VAS)

의 모든 데이터는 평균과 표준편차로 나타내어졌다. 통계 분 석 프로그램으로는 SPSS 18.0 (SPSS Inc., USA)이 사용 되었으며, 모든 통계 분석에서 $\mathrm{p}<0.05$ 를 유의한 수준으로 하였다.

\section{III. 결 과}

\section{1. 각 군의 VAS 변화 비교}

그림 2 는 휴식 후 각 군의 $\mathrm{VAS}$ 변화를 보여준다. $\mathrm{VAS}$ 는 모든 군에서 감소하는 경향을 보였으며, 특히 조합마사지군 에서 가장 큰 감소를 보였다. 또한 대조군 $(\mathrm{p}=0.02)$, 단일마 사지군 $(\mathrm{p}=0.002)$ 그리고 조합마사지군 $(\mathrm{p}=0.014)$ 의 변화 가 통계적으로 유의하였으며, 휴식의 조건에 의한 각 군의 변화 $(\mathrm{F}=3.715, \mathrm{p}=0.035)$ 에서는 대조군과 조합마사지군 사이 $(\mathrm{p}=0.011)$ 에서만 유의한 변화를 보였다.

\section{2. 각 군의 체후굴 측정 및 $\mathrm{EMG}$ 분석 비교}

그림 3 은 각 군의 자극 조건에 따른 실험 전과 후의 체후 굴 후 바닥에서 턱까지의 높이를 측정한 평가 (a)와 EMG$\mathrm{RMS}$ 값 (b)의 변화를 보여준다. 체후굴 평가와 EMG-RMS

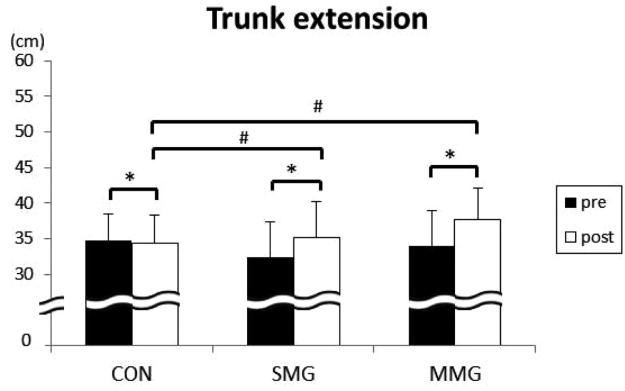

(a)

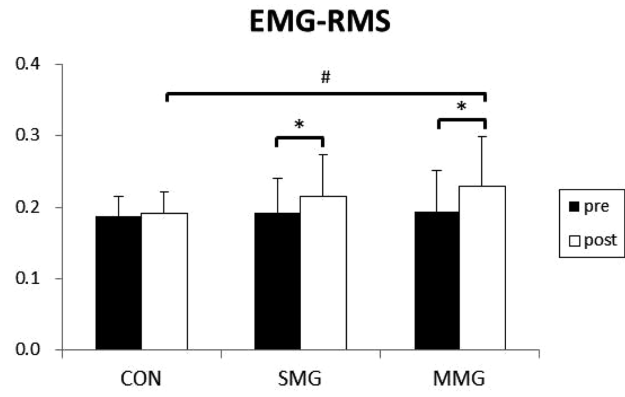

(b)

$(*:$ t-test, \#: ANCOVA, $p<0.05)$

그림 3. (a) 체후굴과 (b) EMG-RMS 값의 변화

Fig. 3. Changes in (a) the trunk extension, and (b) the EMG-RMS values 
값은 조합마사지군이 다른 군들에 비해 실험 전의 값보다 더 큰 폭으로 증가하였다.

아무런 자극이 없이 누어서 휴식을 취한 대조군에서 체후 굴 측정값은 실험 후의 결과가 실험 전보다 유의하게 감소 $(\mathrm{p}=0.015)$ 하였으나, EMG-RMS의 값의 변화는 반대로 증 가하는 경향을 보였지만 유의하지 않았다.

지압마사지를 받은 단일마사지군에서 체후굴 측정값은 실 험 후의 결과가 실험 전보다 매우 유의하게 증가 $(\mathrm{p}=0.001)$ 하였으며, $\mathrm{EMG}-\mathrm{RMS}$ 의 값의 변화도 유의하게 증가 $(\mathrm{p}=$ 0.002)하는 경향을 보였다.

온열과 지압마사지를 동시에 받은 조합마사지군의 체후굴 측정값은 유의하게 증가 $(\mathrm{p}=0.02)$ 하였으며, $\mathrm{EMG-RMS} \mathrm{값}$ 도 유의하게 증가 $(\mathrm{p}=0.027)$ 하였다.

또한 체후굴 측정 $(\mathrm{ANCOVA}, \mathrm{F}=16.103, \mathrm{p}=0.0004)$ 에 서는 대조군과 단일마사지군 사이 $(\mathrm{p}=0.008)$ 그리고 대조 군과 조합마사지군 사이 $(\mathrm{p}=0.001)$ 에서 자극 조건에 따른 변화의 차이가 유의하게 나타났다. 단일마사지군에 비해 조 합마사지군의 실험 전과 후의 체후굴 측정값 변화 차이는 더 크게 나타났으나 두 군 사이의 변화 차이는 유의하지 않 았다 $(\mathrm{p}=0.176)$. EMG-RMS (ANCOVA, $\mathrm{F}=3.719, \mathrm{p}=$ $0.042)$ 에서는 대조군과 조합마사지군의 실험 전과 후의 변

\section{3. 각 군의 HRV 변화 비교}

각 군의 $\mathrm{HRV}$ 분석결과인 그림 4 에서는 교감신경의 지표

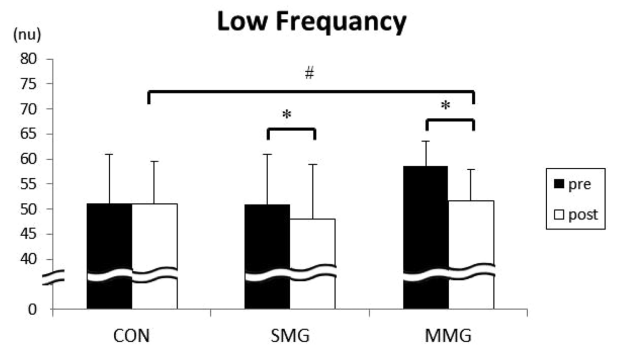

(a)

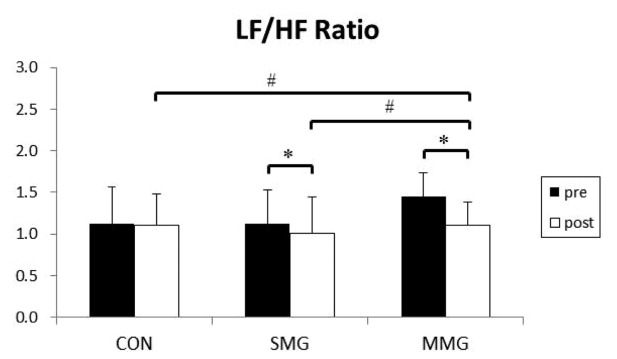

(c)

인 $\mathrm{LF}$ 의 상대값 변화 (a), 부교감신경의 지표인 $\mathrm{HF}$ 의 상 대값 변화 (b), 그리고 $\mathrm{LF}$ 와 $\mathrm{HF}$ 에 따른 $\mathrm{LF} / \mathrm{HF}$ 비의 변화 (c) 및 분당 심박수의 변화를 보여준다. $\mathrm{HRV}$ 의 시간영역 분 석결과에서는 단일마사지군이 실험 전에 비해 실험 후 가장 큰 감소를 나타냈으며, 반면 주파수영역 분석결과에서는 조 합마사지를 수행하였을 때 다른 실험군들에 비해 $\mathrm{LF} / \mathrm{HF}$ 비 의 감소가 크게 나타났다.

대조군의 실험 후 $\mathrm{LF}$ 상대값은 실험 전의 값에 비해 소 폭 증가하는 경향을 보였으나 유의하지 않았으며, $\mathrm{HF}$ 상대 값도 증가하는 추세를 보였으나 실험 전의 값과 유의한 차 이가 나타나지 않았다. $\mathrm{LF} / \mathrm{HF}$ 비는 실험 후 감소하는 경향 을 보였으나 유의하지 않았다. 또한 평균심박수는 실험 전에 비해 증가하였지만 유의하지 않았다.

단일마사지군에서 $\mathrm{LF}$ 상대값은 실험 전에 비해 실험 후 유의하게 감소 $(\mathrm{p}=0.011)$ 하였으며 $\mathrm{HF}$ 의 상대값은 실험 후 유의하게 증가 $(\mathrm{p}=0.011)$ 하였다. $\mathrm{LF} / \mathrm{HF}$ 비는 실험 후 유 의하게 감소 $(\mathrm{p}=0.016)$ 하였으며, 평균심박수도 유의하게 감 소 $(\mathrm{p}=0.001)$ 하였다.

조합마사지군의 $\mathrm{LF}$ 상대값은 단일마사지군과 유사하게 유의한 감소 $(\mathrm{p}=0.001)$ 를 보였으며, $\mathrm{HF}$ 도 유의하게 증가 하였다 $(\mathrm{p}=0.001) . \mathrm{LF} / \mathrm{HF}$ 비는 감소하는 경향이 나타났으 며 통계적으로 유의했다 $(\mathrm{p}=0.02)$. 그리고 실험후의 평균심 박수도 유의하게 감소하였다 $(\mathrm{p}=0.002)$.

각 군의 실험 전/후 변화의 유의성을 위해 실시한 ANCOVA 의 결과로 $\mathrm{LF}$ 와 $\mathrm{HF}$ 상대값의 변화 $(\mathrm{F}=6.008, \mathrm{p}=0.006)$

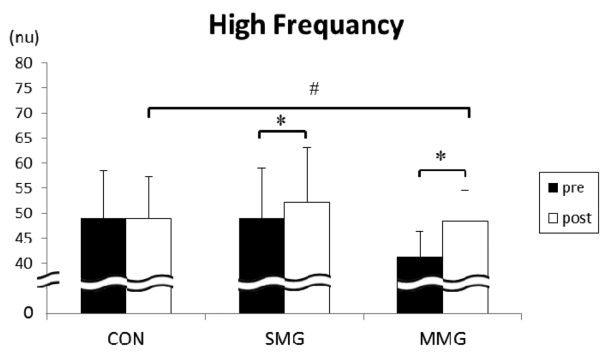

(b)

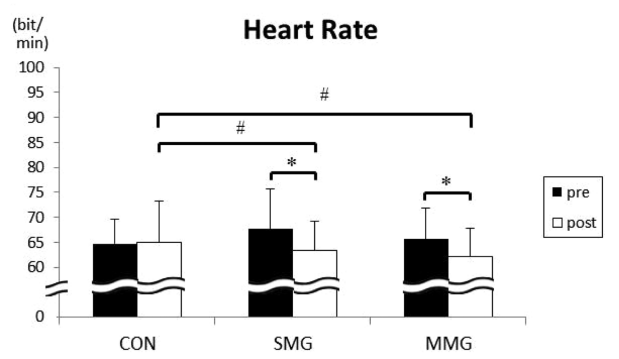

(d)

$(*: \mathrm{t}$-test, $\#:$ ANCOVA, $p<0.05)$

그림 4. (a) 저주파의 상대값, (b) 고주파의 상대값, (c) LF/HF 비 그리고 (d) 평균심박수의 변화

Fig. 4. Changes in (a) the normalized unit of low frequency, (b) the normalized unit of high frequency, (c) the LF/HF ratio and (d) the average of heart rate 
는 대조군과 조합마사지군 사이에서만 자극 조건에 따른 유 의한 차이 $(\mathrm{p}=0.002)$ 가 나타났으며, $\mathrm{LF} / \mathrm{HF}$ 비의 변화 $(\mathrm{F}=$ $7.944, \mathrm{p}=0.002)$ 에서는 조합마사지군의 변화에 대해 대조 군 $(\mathrm{p}=0.013)$ 과 단일마사지군 $(\mathrm{p}=0.003)$ 에서 유의한 차이 를 보였다. 평균심박수의 변화 $(\mathrm{F}=5.932, \mathrm{p}=0.006)$ 는 대조 군과 단일마사지군 사이의 변화 $(\mathrm{p}=0.003)$, 대조군과 조합 마사지군 사이의 변화 $(\mathrm{p}=0.009)$ 가 유의한 차이를 보였다.

\section{IV. 고 찰}

현대인들은 교감신경과 부교감신경의 균형이 조화롭지 않 다. 대부분은 일과 중 과로를 하거나 스트레스가 쌓이고, 휴 식 시에도 TV시청이나 인터넷을 하는 둥 흥분상태가 지속 되는 생활습관을 갖고 있어 교감신경의 활동이 우세하다. 또 한 장시간의 업무 환경은 근골격계를 손상시킨다. 게다가 초 고령화 시대에 진입한 지금, 노인의 인구는 지속적으로 늘 어나고 있으며 노화에 따른 신체 기능의 전반적인 쇠퇴로 인한 근골격계의 퇴화와 자율신경계의 부조화 현상이 나타 난다. 이러한 사회 현상 속에서 마사지에 대한 긍정적 인식 이 확대되고 있으나 조합마사지가 인체에 미치는 영향에 대 한 연구는 거의 전무한 상태이다. 본 연구에서는 실험 참여 자의 척추에 일정시간 동안 지압과 온열의 조합마사지를 수 행하였을 때 나타나는 영향을 관찰하기 위해 외부 환경이 실험에 미치는 영향을 최소화하기 위해 기존 연구에서 사용 된 비침습적 생체신호 측정법과 평가를 마사지 전과 후에 수행하였다[6-9,22-24]. 실험 참여자의 긴장 완화와 안정에 미치는 영향을 보기 위해 $\mathrm{VAS}, \mathrm{EMG}$ 와 $\mathrm{ECG}$ 측정이 사용 되었으며, 이들 측정과정과 휴식을 고려하여 그림 1 과 같이 실험을 설계하였다. 특히 측정 과정에서 체후굴 평가와 같은 단기간의 운동적 평가가 실험참여자의 생체신호에 영향을 미 칠 수도 있음을 고려하여 대조군도 다른 실험군과 동일한 과 정으로 실험을 수행하였으며, 대조군의 $\mathrm{HRV}$ 결과에 큰 변 화가 없는 것으로 나타나 체후굴 측정과정이 $\mathrm{ECG}$ 에 영향 을 미치지 않는 것으로 판단된다. 또한 $\mathrm{ECG}$ 측정 전에 데 이터 수집 및 저장과 $\mathrm{ECG}$ 측정 시스템 등으로 인해 대기 시간이 소요되며 이때 실험 참여자는 누운 상태로 있어 체 후굴 수행에 대한 충분한 휴식될 것으로 사료된다. 실험참 여자의 심리적 스트레스 완화 정도를 평가하기 위해 주관적 스트레스 평가인 $\mathrm{VAS}$ 를 사용하였으며, 휴식 전후 심리적 스트레스가 대조군에 비해 단일마사지군과 조합마사지군에 서 더 큰 감소를 보였다. 이는 김용대 등[8]와 Ogura 등[27] 에서 나타난 연구 결과와 유사한 경향이며, 특히 조합마사 지와 대조군 간의 변화에 대한 유의성을 통해 조합마사지가 인체의 심리적 긴장상태의 이완에 효과적임을 볼 수 있다.
마사지가 인체 척추의 근 기능에 미치는 영향을 알아보기 위해 수행된 체후굴 평가의 결과로 단일마사지군과 조합마 사지군에서 휴식 전의 측정 값에 비해 각각 $8.4 \%$ 와 $10.8 \%$ 의 유의한 증가를 보였으며, 이는 권형수 등[18]이 무용수 를 대상으로 한 연구에서 나타난 안마사에 의한 30 분간의 지압마사지 후 실험 전 보다 약 $15 \%$ 정도 증가하는 결과와 유사하다. 이와 같은 선행연구와 유사한 결과를 통해 지압 마사지가 근육의 피로를 해소하고 이완 작용을 촉진시켜 인 체의 유연성을 향상시켜 육체적 스트레스의 완화에 영향을 미친 것을 알 수 있다. 또한 체후굴 측정과 동시에 수행된 척추세움근 $\mathrm{EMG}$ 측정에서도 단일마사지군과 조합마사지군 의 휴식 후 $\mathrm{RMS}$ 최대평균값이 각각 $11.9 \%$ 와 $17.9 \%$ 의 유 의한 증가를 보여 체후굴 측정 결과와 유사한 경향을 보였 다. 이와 유사한 선행연구로 Shambaugh[23]은 허리에 동 일한 부하를 취하였을 시 마사지사에 의한 지압마사지를 받 은 경우에서 근육의 활성도가 아무런 처치를 취하지 않은 대조군에 비해 최대근력이 약 $25 \%$ 정도 감소되어 근육의 안정 및 최대활성화가 증가함을 제시하였다. 이러한 체후굴 측정과 최대근력측정을 통해 종전의 연구와 유사한 결과를 확인 할 수 있었으며 단순 휴식에 비해 단기적인 마사지가 인체의 척추세움근을 비롯한 여러 근육의 이완에 영향을 주 어 유연성 향상과 같은 긍정적인 효과가 예상된다[3,9]. 특히 본 연구에서 단일마사지군에 비해 조합마사지군의 증가율이 더 크게 나타난 점에서 지압 단일마사지에 비해 온열과 지 압의 조합마사지가 근력의 회복 및 향상에 더 큰 영향을 줄 수 있는 것으로 판단된다. 이는 둘 이상의 조합한 자극이 인 체에 더 긍정적인 영향을 줄 수도 있을 것이라는 Lee 의 이 론적 주장을 실험적으로 증명한 것이다[24].

$\mathrm{ECG}$ 측정에 따른 $\mathrm{HRV}$ 의 시간영역 분석결과에서는 대 조군을 제외한 단일마사지군과 조합마사지군에서 평균심박 수가 휴식 후 각각 $6.6 \%$ 와 $5.6 \%$ 의 유의한 감소를 보였으 며, 주파수 영역 분석에서도 두 마사지군에서 휴식 후 $\mathrm{LF}$ 의 감소와 $\mathrm{HF}$ 의 증가로 인해 $\mathrm{LF} / \mathrm{HF}$ 비가 단일마사지군에 서 $10.1 \%$, 조합마사지군에서 $23.8 \%$ 의 유의한 감소를 보였 다. 이는 김용대 등[8]의 연구에서 나타난 마사지의 세기에 따라 마사지 후 평균심박수와 $\mathrm{LF} / \mathrm{HF}$ 비가 각각 최대 $9 \%$, $32.3 \%$ 로 감소한 결과와 유사한 경향을 보인다. 이러한 평 균심박수와 $\mathrm{LF} / \mathrm{HF}$ 비는 부교감신경의 활성 정도와 관련이 있으며 이들의 감소는 부교감신경의 활성이 증가했음을 보 여준다[7,8]. 이에 따라 마사지자극은 부교감신경의 활성을 증가시켜주며 이로 인하여 피검자의 혈압 및 심장박동을 감 소시켰을 것으로 사료되며 이를 통하여 피검자의 스트레스 의 감소를 유발시킬 것으로 기대된다[14,15,20]. 이와 같은 결과는 마사지가 자율신경계에 영향을 미쳐 교감신경과 부 
교감신경을 활성화시키는데 이들의 길항 작용을 통해 인체 의 조직과 기관의 생리적 균형을 유지하게 되고 이에 따라 혈액순환이 개선되고 스트레스의 해소에 영향을 준다는 의 의를 갖는다[3,4]. 특히 다른 실험 결과에서는 나타나지 않 은 단일마사지군과 조합마사지군 간의 자극 조건에 따른 변 화에 대한 통계적인 유의성 $(\mathrm{p}<0.05)$ 이 $\mathrm{LF} / \mathrm{HF}$ 비의 결과에 서 나타난 점에서 조합마사지가 단일마사지에 비해 자율신 경계 중 부교감신경을 활성화 더 큰 영향을 미치며 인체의 스트레스 완화에 효과적일 것으로 사료된다.

\section{V. 결 론}

본 연구에서는 생체신호 측정 및 분석을 통해 조합마사지 가 근 기능 향상 및 스트레스 완화에 효율적임을 알아보기 위해 VAS, EMG 및 ECG 측정을 이용하여 대조군, 단일마 사지군 그리고 조합마사지군의 세 가지 자극 조건에 따라 허 리의 유연성과 최대근력 및 자율신경계의 변화 등을 관찰한 결과 다음과 같은 결론을 얻었다.

1. 심리적 스트레스 평가를 위한 VAS에서는 모든 군에서 유의한 변화가 있었으며, 특히 조합마사지군에서 가장 큰 감 소를 보였다.

2. 체후굴 평가와 $\mathrm{EMG}$ 측정에서는 대조군을 제외한 두 마사지군에서 마사지 후 유의한 증가를 보였다. 조합마사지 군에서 단일마사지군 보다 더 큰 증가를 보였으나 두 마사 지군 사이에서 유의한 변화는 보이지 않았다.

3. $\mathrm{HRV}$ 를 통한 자율신경계의 변화에서 대조군을 제외한 두 마사지군의 $\mathrm{LF} / \mathrm{HF}$ 비의 마사지 후 유의한 감소를 확인 하였다. 특히 자극 조건에 따른 각 군의 변화에 대해 모든 군 사이에서 통계적인 유의성이 나타났다.

4. 평균심박수는 대조군을 제외한 두 마사지군에서 마사 지 후 유의한 감소가 나타났다.

따라서 마사지 적용이 심리적 안정, 유연성 및 최대근력 향상에 기여할 뿐 아니라 부교감신경의 활성에 효과적임을 보였으며, 특히 조합마사지는 단일마사지에 비해 자율신경계 의 안정화에 효과가 더 긍정적임을 확인하였다. 추후의 연구 에서는 온열 단일 자극이 가능하도록 조합 자극기의 시스템 을 수정하여 본 실험에서 시스템적 한계로 수행하지 못한 온 열 단일 자극에 대한 효과를 검증하고자 한다. 또한 뇌파, 생화학적 검사 등의 다양한 분석 파라미터를 통해 조합마사 지에 의한 인체의 생리적 변화를 확인하고자 한다. 본 연구 를 통하여 온열과 지합의 조합마사지가 스트레스를 효율적 으로 감소시킴을 확인할 수 있었으며, 근골격계의 통증 예 방 및 육체적 스트레스 완화에 도움이 되는 비외과적 처치 방법으로 제안될 수 있을 것이다.

\section{References}

[1] S. Selye, History and present status of the stress concept, In Goldberger L Editor, Handbook of stress, The Free Press, 1982. pp. 7-17.

[2] 강건일, "대체의학 현상에 대한 고찰", 대한의사협회지, 제 41 권, 제 12 호, pp. 1217-1221, 1998.

[3] A.N. Christopher, R. James, and W.H. James, "A meta-analysis of massage therapy research," Psychol. Bull., vol. 130, no. 1, pp. 3-18, 2004.

[4] A.I. Paul, Handbook of cardiac anatomy, physiology, and devices, Humana Press, 2009 pp. 183-187.

[5] I. Shojiro, "Biological activities caused by far-infrared radiation,” Int. J. Biometeorol., vol. 33, pp. 145-150, 1989.

[6] S.W. Jun, S.J. Park, S.G. Jung, T.M. Shin and H.R. Yoon, “A research for evaluation on stress change via thermotherapy and massage," 30th Annual International Conference of the IEEE, Vancouver, Canada, Aug, 2008, pp. 4820-4823.

[7] M. Diego, T. Field, C. Sanders and M. Hernandez-Reif, "Massage therapy of moderate and light pressure and vibration effects on EEG and heart rate," Int. J. Neurosci., vol. 114, no. 1, pp. 31-44, 2004.

[8] Y.D. Kim, Y.S. Chang, D.H. Choi, H.J. Lee, and K.S. Tae, "Evaluation of immediate effects of an electrical massager on stress relaxation using the heart rate variability(HRV)," Journal of the Korean Society for Precision Engineering, vol. 27, no. 6, pp. 75-81, 2010.

[9] S.Y. Lee, and K.T. Yoo, "The effects of sports massage on hamstring and quadriceps after maximal exercise test," Health \& Sports Medicine, vol. 11, no. 3, pp. 41-51, 2009.

[10] B.C. Clark, T.M Manini and L.L. Ploutz-Snyder, "Derecruitment of the lumbar musculature with fatiguing trunk extension exercise," Spine, vol. 28, no. 3, pp. 282-287, 2003.

[11] G.L. Soderberg, Selected topics in surface electromyography for use in the occupational setting, US Dept of Health and Human Services, Public Health Service Press, 1992, pp. 91100.

[12] Y.J. Cho, and J.Y. Kim, "The effect of the signal stationarity on the EMG frequency analysis," Journal of the Ergonomics Society of Korea, vol. 29, no. 2, pp. 183-188, 2010.

[13] T.Y. Fukuda, J.O. Echeimberg, J.E. Pompeu, P.R. Lucareli, S. Gabelotti, R.O. Gimenes and A. Apolinario, "Root mean square value of the electromyographic signal in the isometric torque of the quadriceps, hamstrings and brachial biceps muscles in female subjects," J. Applied, vol. 10, no. 1, pp. 31-39, 2010.

[14] Y.C. Arai, T. Ushida, T. Osuga, T. Matsubara, K. Oshima, K. Kawaguchi, C. Kuwabara, S. Nakao, A. Hara, C. Furuta, E. Aida, S. Ra, Y. Takagi and K. Watakabe, "The effect of acupressure at the extra 1 point on subjective and autonomic responses to needle insertion," Anesth. Analg., vol. 107, no. 2, pp. 661-664, 2008.

[15] M.V. Kamath, and E.L. Fallen, "Power spectral analysis of heart rate variability: a noninvasive signature of cardiac autonomic function," Crit. Rev. Biomed. Eng., vol. 21, no. 3, pp. 245-311, 1993.

[16] A. Malliani, F. Lombardi, and M. Pagani, "Power spectrum analysis of heart rate variability: a tool to explore neural regulatory mechanism," Br. Heart. J., vol. 71, no. 1, pp. 1-2, 1994. 
[17] N. Montano, T.G. Ruscone, A. Porta, F. Lombardi, M. Pagani, and A. Malliani, "Power spectrum analysis of heart rate variability to assess the changes in sympathovagal balance during graded orthostatic tilt," Circulation, vol. 90, no. 4, pp. 1826-1831, 1994.

[18] H.S. Kwon, and M.S. Park, "The Effects of sports massage on the increasing flexibility of dancer," Journal of Coaching Development, vol. 8, no. 4, pp. 333-340, 2008.

[19] Y. Yoshitake, H. Ue, M. Miyazaki, and T. Moritani, “Assessment of lower-back muscle fatigue using electromyography, mechanomyography, and near-infrared spectroscopy," Eur. $J$. Appl. Physiol., vol. 84, no. 3, pp. 174-179, 2001

[20] C. Toro-Velasco, M. Arroyo-Morales, C. Fernández de Las Peñas, J.A. Cleland and F.J. Barrero-Hernández, "Short-term effects of manual therapy on heart rate variability, mood state, and pressure pain sensitivity in patients with chronic tension-type headache: a pilot study," J. Manipulative. Physiol. Ther., Vol. 32, No. 7, pp. 527-535, 2009.

[21] H.K. Rha, K.J. Lee, K.K. Cho, S.C. Park, H.K. Park, and C.R. Choi, "Neurosurgery for the Elderly," J. Korean Neurosurg., vol. 26, no. 12, pp. 1699-1704, 1997.

[22] E. Suter, G. McMorland, W. Herzog, and R Bray, "Decrease in quadriceps inhibition after sacroiliac joint manipulation in patients with anterior knee pain," J. Manipulative. Physiol. Ther., vol. 22, no. 3, pp. 149-153, 1999

[23] P. Shambaugh, "Changes in electrical activity in muscles resulting from chiropractic adjustment: a pilot study," $J$. Manipulative Physiol. Ther., vol. 10, no. 6, 1987.

[24] D.W. Lee, J.H. Park, S.N. Eom, S.H. Cho, J.S. Lee and H.S. Kim, "Effects of combined stimulation on the autonomic nervous system: a pilot study," World Academy of Science, Engineering and Technology 60, Phuket, Thailand, Dec, 2011, pp. 618-621.

[25] M.H. Lee, J.Y. Kim, C.G. Song, and N.G. Kim, “A Study on the driver's drowsiness warning system using oxygen and color," J. of Biomed. Eng. Res., vol. 21, no. 2, pp. 175-180, 2000.

[26] Y.S. Kang, "Stress management and mind-body medicine: focusing on relaxation and meditation," J. Korean Med. Assoc., vol. 54, no. 3, pp. 284-293, 2011.

[27] T. Ogura, M. Tashiro, M. Masud, S. Watanuki, K Shibuya, K. Yamaguchi, M, Itoh, H. Fukuda, K. Yanai. "Cerebral metabolic changes in men after chiropractic spinal manipulation for neck pain.," Altern. Ther. Health Med., vol. 17, no. 6, pp. 12-17, 2011 